\title{
Kepercayaan sebagai Mediasi Kepuasan Pengguna Online Shopping di Indonesia
}

\section{Trust as Mediating Satisfaction of Online Shopping Users in Indonesia}

\author{
Siska Ernawati Fatimah'1, Ario Purdianto' ${ }^{1}$, Dita Septiani' ${ }^{1}$ Nadhira Azzahra ${ }^{1 *}$ \\ 1) Manajemen, Fakultas Ekonomi, Universitas Swadaya Gunung Jati, Cirebon, Indonesia \\ *Coresponding Email: siskafatimah12@gmail.com
}

\begin{abstract}
Abstrak
Ramainya layanan untuk marketplace di Indonesia menimbulkan perubahan pola berbelanja masyarakat untuk memenuhi kebutuhan sehari-hari. Perubahan pola berbelanja tersebut yang semula offline menjadi online semakin meningkat pada masa pandemi Covid 19, hal ini memberikan peluang para pengelola marketplace dengan memanfaatkan penggunaan media sosial untuk berbelanja online dalam memenuhi kebutuhannya. Selain itu memacu para pengelola marketplace berlomba-lomba untuk memberikan kepuasan terhadap penggunanya. Tujuan penelitian untuk mengetahui peran kepercayaan sebagai variabel mediasi pada pengaruh antara transaksi online dan kepuasan pengguna aktif marketplace Tokopedia di Indonesia khususnya di Kota Cirebon. Teknik pengumpulan data dalam penelitian ini dengan menggunakan kuesioner dengan metode accidental sampling yang melibatkan 100 pengguna aktif marketplace Tokopedia di kota Cirebon sebagai responden. Analisis data yang digunakan yaitu statistik deskriptif dan inferensial yaitu Structure Equation Model dengan menggunakan SmartPLS 3. Hasil dari analisis data menunjukan transaksi online berpengaruh terhadap kepuasan pengguna secara langsung dan transaksi online mempengaruhi kepuasan pengguna dengan mediasi kepercayaan.
\end{abstract}

Kata Kunci: Transaksi Online, Kepercayaan, Kepuasan Pengguna.

\section{Abstract}

The rise of services for marketplaces in Indonesia has led to changes in people's shopping patterns to meet their daily needs. The change in shopping patterns from offline to online has increased during the COVID-19 pandemic, this provides an opportunity for marketplace managers to take advantage of the use of social media to shop online to meet their needs. In addition, it spurs marketplace managers to compete to provide satisfaction to its users. The purpose of the study was to determine the role of trust as a mediating variable on the influence between online transactions and the satisfaction of active users of the Tokopedia marketplace in Indonesia, especially in the city of Cirebon. The data collection technique in this study used a questionnaire with the acidental sampling method which involved 100 active users of the Tokopedia marketplace in Cirebon City as respondents. The data analysis used is descriptive and inferential statistics, namely the Structure Equation Model using SmartPLS 3. The results of data analysis show that online transactions directly affect user satisfaction and online transactions affect user satisfaction with trust mediation.

Keywords: Online Transactions, Trust, User Satisfaction.

How to Cite: Fatimah, S.E., Purdianto, A., Septiani, D. \& Azzahra, N. (2021). Kepercayaan Sebagai Mediasi Kepuasan Pengguna Online Shopping Di Indonesia. JKBM (Jurnal Konsep Bisnis dan Manajemen). 8 (1): 81-91 
Fatimah, S.E., Purdianto, A., Septiani, D. \& Azzahra, N. (2021). Kepercayaan Sebagai Mediasi Kepuasan Pengguna Online ...

\section{PENDAHULUAN}

E-commerce merupakan suatu transaksi penjualan yang dilakukan melalui media internet untuk memenuhi kebutuhan manusia. Menurut (Kotler \& Keller, 2016) dalam mengungkapkan $e$ commerce adalah penyebaran informasi, pembelian dan penjualan, serta pemasaran produk atau jasa melalui media elektronik seperti internet atau televisi. E-commerce di dalamnya melibatkan transfer dana secara elektronik, melakukan pertukaran data elektronik, menggunakan sistem inventory otomatis, dan sistem pengumpulan data secara otomatis (Andhini \& Khuzaini, 2017)

Dari sepuluh negara di dunia pada tahun 2020 pengguna e-commerce tertinggi di dunia berdasarkan hasil survei We Are Social pada April
2021 dilihat pada gambar 1 di mana sebanyak $88,1 \%$ pengguna internet di Indonesia menggunakan pelayanan e-commerce untuk membeli produk tertentu. Posisi kedua ditempati Inggris dengan $86,9 \%$ pengguna internet yang memakai e-commerce. Kemudian, pengguna internet yang memakai e-commerce di Filipina sebesar 86,2\%. Sekitar $85 \%$ pengguna internet di Thailand dan Malaysia juga memanfaatkan layanan tersebut. Pengguna internet di Jerman, Irlandia, dan Korea Selatan yang memanfaatkan e-commerce berkisar 84\%. Sementara, pengguna internet yang memakai e-commerce di Italia dan Polandia masingmasing sebesar $82,9 \%$. Hal ini dapat dilihat dari gambar 1 di bawah ini:

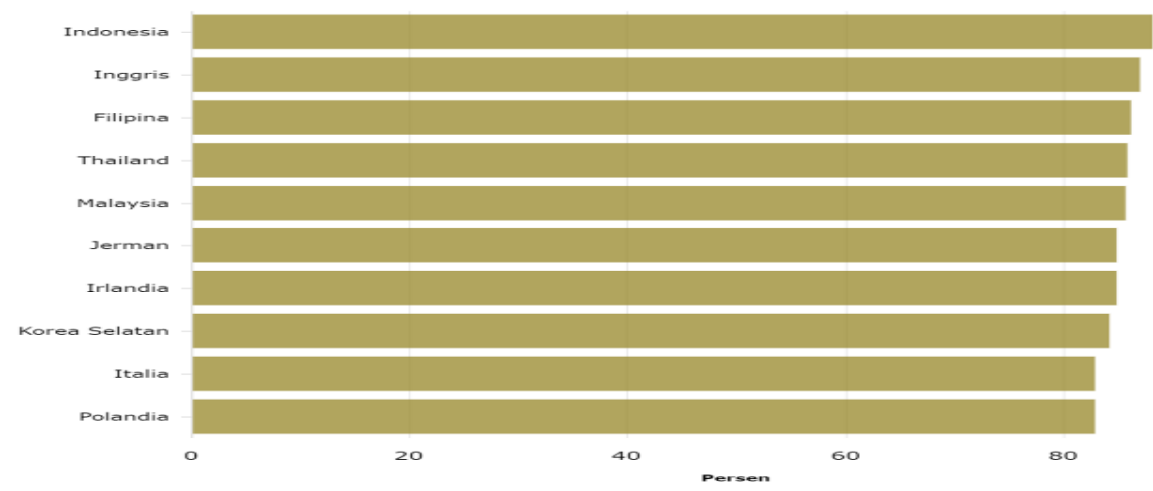

Gambar 1. Negara Pengguna E-Commerce Tertinggi Sumber : KataData, 2020

Indonesia sebagai negara tertinggi dalam pening- akan terus meningkat dari tahun ke tahun. Prekatan jumlah pengguna e-commerce dari sepuluh diksi peningkatan jumlah pengguna e-commerce di negara di dunia pada tahun 2020. Dari hal tersebut Indonesia disajikan pada gambar 2 di bawah ini. memprediksi pengguna e-commerce di Indonesia

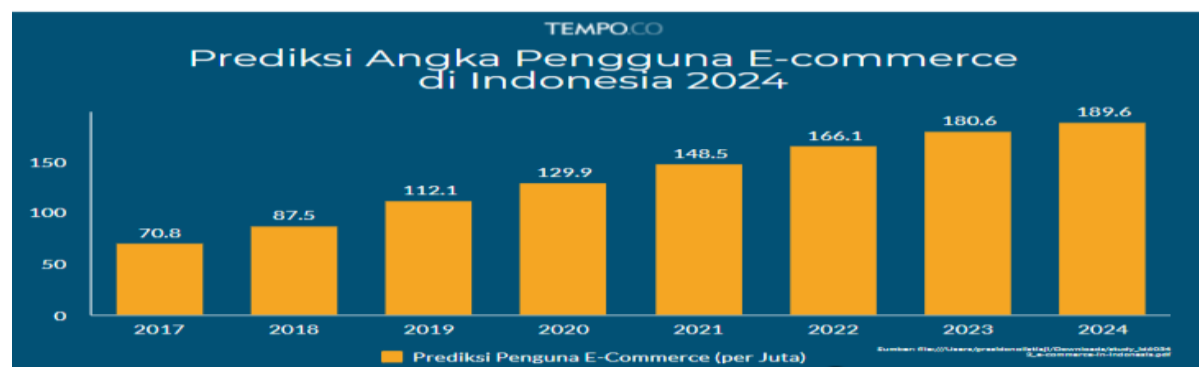

Gambar 2. Prediksi Pengguna E-Commerce Indonesia Sumber : Tempo.Co.id, 2019 
Indonesia diprediksi untuk pengguna e- pengguna, sedangkan pada tahun 2022 diestimasi commerce meningkat hingga 189,6 juta pengguna sebanyak 166,1 juta pengguna dan tahun 2023 pada 2024. Sejak tahun 2017 berjumlah 70,8 juta mencapai 180,6 juta pengguna. Dengan terus mepengguna e-commerce. Tahun 2018, sebanyak ningkatnya prediksi jumlah pengguna e-com-merce 87,5 juta pengguna e-commerce. Pada tahun 2020, di Indonesia, membuktikan bahwa tingkat adopsi mencapai 129,9 juta pengguna e-commerce. e-commerce di Indonesia tertinggi di dunia dapat Tahun 2021, diperkirakan sebanyak 148,9 juta dilihat gambar 3 di bawah ini:

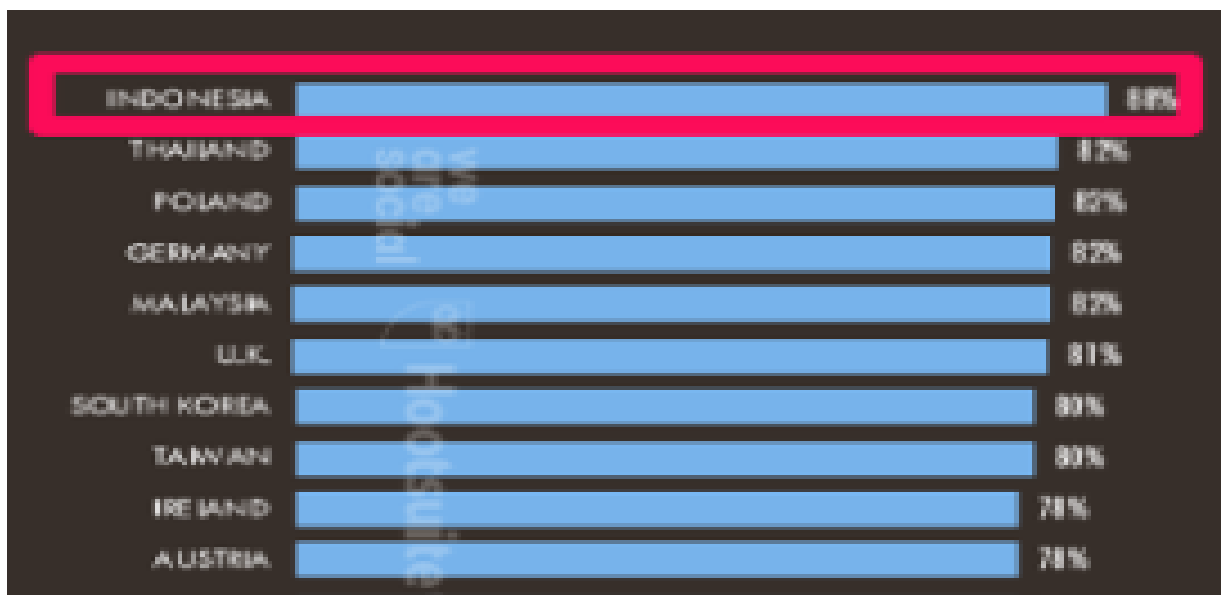

Gambar 3. Adopsi E-commerce Dunia

Sumber : WebIndex, 2020

Dari gambar 3 di atas dapat dilihat bahwa Indonesia berdasarkan data We Are Social merupakan negara dengan adopsi ecommerce terbesar di dunia mencapai $88 \%$ dari seluruh pengguna internet yang ada di dunia. Thailand dengan adopsi e-commerce mencapai $87 \%$. Polandia, Jerman, dan Malaysia mencapai 82\%. United Kingdom mencapai 81\%. South Korea dan Taiwan 83\%. Dan Irlandia dan Australia mencapai 78\%. Sedangkan negara lainnya mencapai di bawah $78 \%$.

Perusahaan marketplace adalah menyediakan platform untuk bertemunya penjual dan pembeli, di mana pembeli dapat melihat produk yang dijual, kemudian perusahaan marketplace mengambil keuntungan melalui komisi dari se- tiap penjualan (Chan, Purwanto, \& Hendratono, 2020). Bentuk platform dalam marketplace berbentuk website maupun aplikasi. Semua proses operasional marketplace, yang terdiri dari pengelolaan website sampai metode pembayaran difasilitasi oleh perusahaan penyedia marketplace (Sumarno \& Alvin, 2021).

Secara tidak langsung, perusahaan marketplace hanya menye-diakan tempat untuk penjual yang akan berjualan dan pelanggan yang sedang mencari produk sehingga transaksi yang mudah dan cepat (Purthi \& Gupta, 2017).

Marketplace di Indonesia yang paling banyak dikunjungi oleh konsumen (traffic share) dapat dilihat pada gambar 4 di bawah ini: 
Fatimah, S.E., Purdianto, A., Septiani, D. \& Azzahra, N. (2021). Kepercayaan Sebagai Mediasi Kepuasan Pengguna Online ...

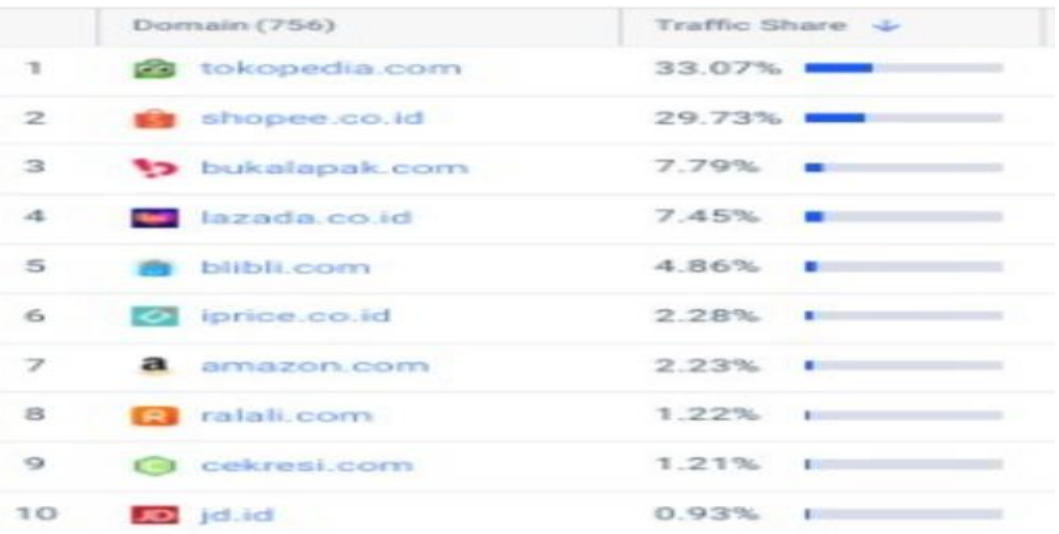

Gambar 4. Sepuluh Marketplace dengan Traffic Share Tertinggi pada Kuartal Pertama Tahun 2021 Sumber : MarketingComunication, 2021

Dari gambar 4 di atas pada kuartal pertama (Q1) bulan Januari sampai dengan April 2021 menunjukkan bahwa tokopedia merupakan marketplace yang paling banyak diakses di internet. Sehingga bulan Maret 2021 traffic share Tokopedia mencapai 33,07\%. Posisi Tokopedia diikuti oleh Shopee diperingkat kedua, dengan traffic share 29,73\%. Posisi ketiga hingga kelima ditempati oleh Bukalapak, Lazada, dan Blibli. Per Maret 2021, traffic share Bukalapak sebesar 7,79\%. Di posisi kelima, blibli dengan traffic share $4,86 \%$.
Selanjutnya, diperingkat keenam sampai kesepuluh, ditempati oleh iPrice, Amazon, Ralali, Cekresi, dan JD.ID. Sehingga dapat disimpulkan tokopedia pada kuartal pertama tahun 2021 menempati traffic share tertinggi. Tingginya traffic share suatu marketplace mencerminkan banyaknya aktivitas yang dilakukan oleh konsumen. Aktivitas yang paling sering dilakukan di marketplace oleh konsumen Indonesia dapat dilihat pada gambar 5 di bawah ini:

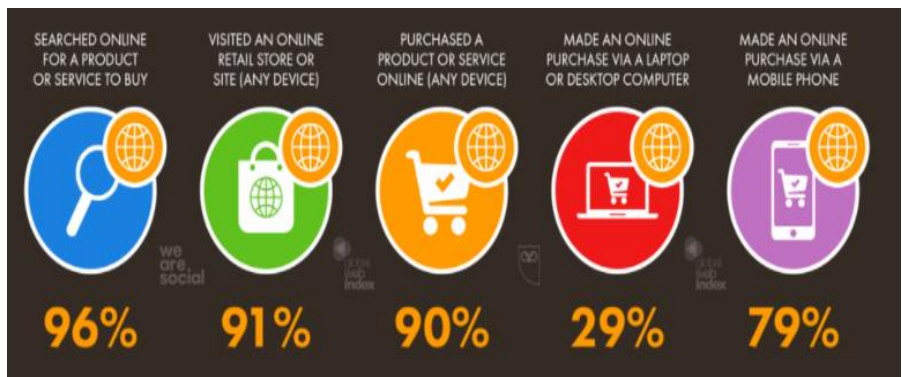

Sumber : WebIndex 2019

Gambar 5. Aktivitas E-commerce di Indonesia

Dari gambar 5 di atas aktivitas konsumen Indonesia pada marketplace dapat dilihat untuk pencarian informasi produk atau jasa sebesar 96\%, mengunjungi toko online 91\%, membeli produk atau jasa 90\%, melakukan pembelian melalui laptop atau desktop 29\%, melakukan pembelian melalui smart- phone 79\%. Hal ini membuktikan bahwa konsumen Indonesia paling banyak melaku-kan pencarian produk atau jasa pada marketplace. Dengan berbagai macam aktivitas yang dilakukan oleh pengguna di marketplace Tokopedia tidak menutup kemungkinan adanya ketidakpuasan yang dirasakan oleh konsu- 
men. Begitupun dengan pengguna Tokopedia di kota Cirebon yang merasakan ketidakpuasan pada saat melakukan transaksi.
Ketidakpuasan tersebut dapat disebabkan oleh beberapa faktor. Di bawah ini terdapat data ketidakpuasan yang dirasakan oleh konsumen pada marketplace yang ada di Indonesia.

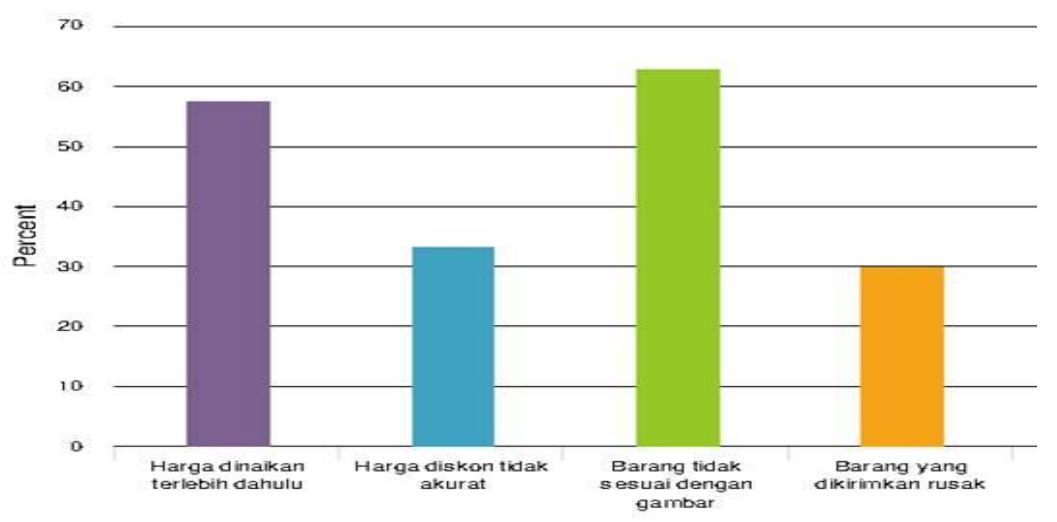

Sumber : Marketing.Co.Id

Gambar 6. Ketidakpuasan Pengguna Marketplace 2019 di Indonesia

Pada gambar 6 di atas terdapat beberapa penyebab penurunan tingkat kepuasan konsumen setelah menggunakan suatu aplikasi marketplace di Indonesia. Secara keseluruhan dapat dilihat bahwa ketidakpuasan pada marketplace adalah barang yang tidak sesuai dengan gambar.

Transaksi online sebagai proses bertemunya konsumen untuk langsung membeli produk atau jasa dari penawaran penjual secara interaktif dan dilakukan secara real-time tanpa perantara melalui media internet itu (Kotler \& Kartajaya, Hermawan Setiawan, 2019). Belanja online adalah salah satu bentuk perdagangan elektronik yang digunakan untuk kegiatan transaksi penjual ke penjual ataupun penjual ke konsumen (Indratno \& Ramaini, 2018). Transaksi online yang dilakukan oleh konsumen diharapkan dapat menimbulkan kepercayaan pada marketplace tersebut (Merdekawati Agustiena, Elvi Sunita Evi, 2021).

Kepercayaan merupakan kesadaran dan merek dengan segala kemungkinan resiko yang perasaan yang dimiliki oleh pelanggan untuk dihadapi karena ekspektasi yang diharapkan memempercayai sebuah produk, yang digunakan oleh miliki hasil yang diinginkan (Wulur, Militina, \&

penyedia jasa sebagai pondasi bisnis dan alat untuk menjalin hubungan dalam jangka panjang dengan pelanggan (Nurhadi \& Azis, 2018). Menurut (Kotler \& Kartajaya, Hermawan Setiawan, 2019) membentuk kepercayaan pelanggan merupakan salah satu cara untuk menciptakan dan mempertahankan pelanggan (Rahmandika, Puji, \& Purwanto, 2020). Kepercayaan memiliki arti sebagai kesediaan pihak untuk rentan terhadap tindakan pihak lain (Mahendra \& Indriyani, 2018)

Kepercayaan pengguna dalam melakukan transaksi pada marketplace muncul karena ekspektasi pengguna pada saat melakukan transaksi berhasil diwujudkan oleh penjual. (Kotler \& Keller, 2016) Trust in the brand is a consumer desire to believe in the brands that are exposed to a risk and hope that the brand will lead to positive results artinya kepercayaan konsumen diartikan sebagai keinginan konsumen untuk mempercayakan suatu 
Fatimah, S.E., Purdianto, A., Septiani, D. \& Azzahra, N. (2021). Kepercayaan Sebagai Mediasi Kepuasan Pengguna Online ...

Achmad, 2020). Kepuasan yang dirasakan oleh konsumen tidak terlepas dari pelayanan yang diberikan oleh marketplace tersebut, di mana tentunya setiap marketplace harus memahami harapan atau keinginan para konsumen serta memberikan pelayanan yang maksimal (Mahendra \& Indriyani, 2018). Hal ini sejalan dengan penelitian yang di ungkapkan oleh (Nurhadi \& Azis, 2018). (Mahsyar, Suharno, \& Abidin, 2020) yang mengungkapkan bahwa maka kepercayaan pelanggan berpengaruh positif dan signifikan terhadap kepuasan pelanggan. Hasil tersebut juga didukung oleh penelitian yang dilakukan oleh (Widjaja, Restiani, \& Araufi, 2020) menyatakan bahwa kepercayaan pelanggan mempunyai pengaruh positif dan signifikan terhadap variabel kepuasan pelanggan.

Bisnis online sedikit berbeda dengan bisnis konvensional, yang membedakannya adalah sarana yang digunakan. Jika dalam bisnis konvensional atau offline, pihak yang terlibat dalam bisnis bertemu dan melakukan interaksi langsung di suatu tempat, namun pada bisnis online pihak terlibat akan bertemu dan berinteraksi melalui media internet tanpa ada batasan waktu dan wilayah (Purthi \& Gupta, 2017).

Salah satu faktor terpenting dalam bisnis online adalah kepercayaan. Artinya, antara pihak harus memiliki rasa kepercayaan terhadap satu sama lain dikarenakan dalam bisnis online pihak memang yang terlibat tidak bertemu secara langsung (Sudaryana, 2020).

Tujuan dalam penelitian ini adalah mengetahui peran kepercayaan sebagai variabel mediasi pada pengaruh antara transaksi online dan kepuasan pengguna aktif marketplace tokopedia di Indonesia khususnya di Kota Cirebon. Kontribusi penelitian ini adalah diharapkan menjadi rujukan untuk para peneliti selanjutnya khususnya mengenai peran kepercayaan sebagai variabel mediasi pada pengaruh antara transaksi online dan kepuasan pengguna aktif marketplace Tokopedia di Indonesia khususnya di Kota Cirebon sehingga diharapkan untuk marketplace di Indonesia dapat menentukan stategi pemasaran agar dapat meminimalkan ketidakpuasan yang dirasakan konsumen pada saat melakukan transaksi online.

\section{METODE PENELITIAN}

Penelitian menggunakan tipe penelitian yang bersifat explanatory research. Penelitian melibatkan masyarakat sebagai pengguna aktif Tokopedia di kota Cirebon. Metode statistik inferensial yang digunakan dalam penelitian ini adalah Partial Least Square (PLS 3).

Marketplace yang mampu mewujudkan harapan pengguna di mana penjual akan mampu melakukan tindakan tertentu yang penting bagi kepercayaan pengguna. Kepercayaan yang tinggi oleh pengguna terhadap marketplace akan dapat memberikan rasa puas konsumen dalam menggunakan produk atau jasa perusahaan (Siregar Aisyah, 2020).

Pengguna online shopping semakin selektif dalam memilih marketplace. Kepercayaan yang tinggi yang diberikan oleh pengguna online shopping akan membentuk kepuasan pengguna dalam melakukan online shopping (Nirawati, Ayu, Safitri, \& Ahmad, 2020). Hal ini diungkapkan bahwa semakin tinggi derajat kepercayaan pada pelanggan, maka akan menyebabkan semakin tinggi pula kepuasan yang dirasakannya (Sugara \& 
Dewantara, 2017). Pernyataan tersebut didukung dengan pernyataan Mital et al 1998 dalam (Susilo, Haryono, \& Mukery, 2018) bahwa setiap pengalaman dan informasi yang baik akan menumbuhkan kepercayaan konsumen terhadap suatu produk manapun. Dikarenakan suatu pengalaman yang baik pada konsumen akan membantu rasa percaya seseorang terhadap produk tersebut. Berdasarkan hasil dari penelitian (Susilo et al., 2018) terdapat adanya hubungan yang signifikan antara kepercayaan terhadap kepuasan. Karena hubungan tersebut saling berkaitan satu sama lain. Dengan demikian diusulkan hipotesis:

H1 : Transaksi online mempengaruhi secara positif terhadap kepuasan pengguna online shopping

Salah satu resiko yang akan dihadapi pengguna yaitu cara bertransaksi antara penjual dan pembeli tidak bertemu dengan langsung. Dikarenakan konsumen sebagai raja sehingga kepuasannya telah menjadi salah satu alat atau dasar teratas untuk menjalankan bisnis yang sukses. Jadi, sebagai penjual harus menjaga kepercayaan dan memberikan pelayanan sebaik mungkin agar konsumen tidak akan kecewa (Latifah, Widayani, \& Normawati, 2020). Kepuasan konsumen yang menjadi evaluasi keseluruhan berdasarkan total pengalaman pembelian dan konsumsi dengan barang atau jasa dari waktu ke waktu (Sudaryana, 2020). Kepuasan konsumen yang memprediksi perilaku konsumen di masa depan dan memperkirakan tingkat penjualan. Namun, produk dan fiturnya juga aktivitas penjualan dan dukungan konsumen menjadi suatu topik terpenting yang dibutuhkan untuk memenuhi atau melampaui kepuasan konsumen (Insana \& Johan, 2020).
Konsumen yang puas biasanya akan membeli atau menggunakan produk itu kembali. Hal ini dapat dibuktikan oleh penelitian (Dhiranty, Suharjo, \& Suprayitno, 2017) menyatakan bahwa hasil penelitiannya terjadi adanya hubungan yang signifikan antara transaksi online shopping dan kepuasan konsumen melalui kepercayaan konsumen. Hal tersebut dapat terjadi, dikarenakan ketiga variabel tersebut memiliki keterkaitan yang erat. Dengan demikan diusulkan hipotesis:

H2 : Kepercayaan mampu memediasi hubungan antara transaksi online terhadap kepuasan pengguna

Populasi penelitian ini yaitu pengguna Tokopedia di Kota Cirebon yang jumlahnya tidak dapat dihitung, sehingga sampel yang diperoleh menggunakan rumus Roscoe (1975) dalam (Sugiono, 2014) sebanyak 100 responden. Metode penelitian menggunakan incidental sampling. Sedangkan teknik penarikan data menggunakan alat bantu berupa kuesioner dengan skala pengukuran instrumen menggunakan skala Likert.

\section{HASIL DAN PEMBAHASAN}

Dalam penelitian ini karekteristik responden dapat di lihat pada tabel di bawah ini:

Tabel 1. Karakteristik Responden

\begin{tabular}{cccc}
\hline Kategori & Uraian & \multicolumn{2}{c}{ Jumlah Persen (\%) } \\
\hline $\begin{array}{c}\text { Jenis } \\
\text { Kelamin }\end{array}$ & Pria & 45 & 47 \\
\hline Usia & Wanita & 55 & 55 \\
\hline & $\geq 24$ tahun & 65 & 65 \\
\hline $\begin{array}{c}\text { Transaksi } \\
\text { online } \\
\text { terakhir }\end{array}$ & $\leq 1$ tahun terkahir & 72 & 72 \\
\hline & $\geq 1$ tahun terakhir & 28 & 28 \\
\hline
\end{tabular}

Sumber : Data Diolah, 2020

Berdasarkan tabel di atas mengenai karakteritik responden dapat disimpulkan bahwa 
Fatimah, S.E., Purdianto, A., Septiani, D. \& Azzahra, N. (2021). Kepercayaan Sebagai Mediasi Kepuasan Pengguna Online ...

responden wanita lebaih banyak sebagai pengguna online shopping dengan usia berada antara 21-23 tahun dan mayoritas melakukan transaksi online secara aktif kurang dari 1 tahun terakhir

Uji kelayakan model menggunakan Smart PLS 3 dengan menilai Model Fit dari sebuah model penelitian. Pada langkah awal mengetahui Evaluation of measurement model dengan melihat nilai Convergent Validity yang dapat dinilai melalui nilai Loading Factor, Average Variance Extracted (AVE) dan communality, sedangkan untuk Discriminant Validity yang dinilai melalui Cross Loading dan akar kuadrat AVE dan untuk korelasi antar konstruk laten dan composite reliability yang diukur dari nilai Cronbach's alpha dan Composite Reliability. Dari hasil pengolahan data dapat dilihat pada tabel 2 berikut ini:

Tabel 2. Konstruk Validitas dan Reliabilitas

\begin{tabular}{|c|c|c|c|c|}
\hline Variabel Penelitian & $\begin{array}{l}\text { Cronbach's } \\
\text { Alpha }\end{array}$ & rho_A & $\begin{array}{l}\text { Compsite } \\
\text { Reliability }\end{array}$ & Average Variance Extracted (AVE) \\
\hline Transaksi Onlone & 0.847 & 0.849 & 0.908 & 0.766 \\
\hline Kepercayaan & 0.865 & 0.875 & 0.902 & 0.649 \\
\hline Kepuasan Pengguna & 0.867 & 0.870 & 0.909 & 0.715 \\
\hline
\end{tabular}

Sumber : Data Diolah, 2020

Setelah ringkasan tabel 2 di atas maka da- bel. Pengujian selanjutnya pada tahapan kedua pat dilihat nilai Composite Reliability > 0.7 yang yaitu pengujian model struktural yang dapat berarti bahwa variabel penelitian ini adalah relia- disajikan pada gambar di bawah ini.

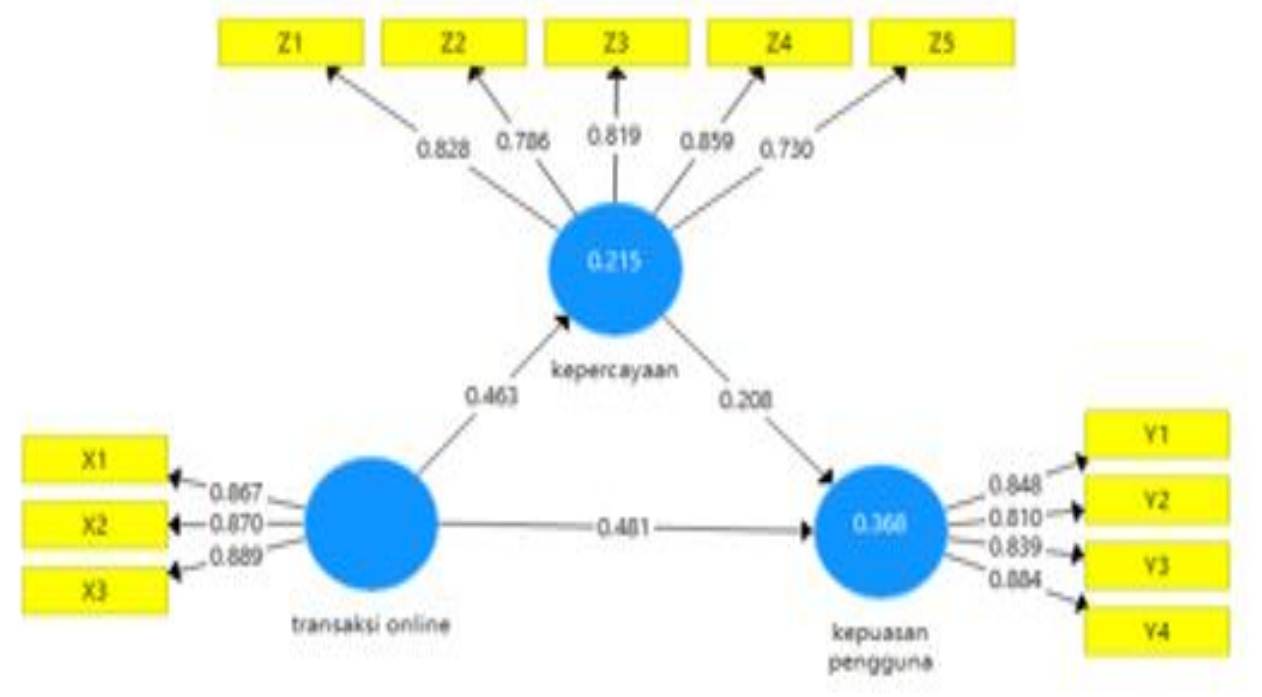

Gambar 1. Model Struktural

Hasil model struktural pada gambar 7 memperlihatkan nilai outer Loading $>0.7$ sehingga dapat dikatakan variabel memiliki validitas yang baik.

Pengujian hipotesis didasarkan pada hasill analisis model SEM PLS 3 mengandung seluruh variabel pendukung di uji hipotesis. Model PLS 3 dengan variabel transaksi online, kepercayaan sebagai variabel mediasi menerangkan bahwa tambahan sebagai penjelasan kepuasan pengguna 
Maka dari itu dapat diinterpertasikan hubungan antar variabel pada tabel 3 di bawah ini.

Tabel 3. Hasil Pengujian Hipotesis

\begin{tabular}{lcc}
\hline Variabel Penelitian & T statistic & P Values \\
\hline Transaksi Online -) kepuasan pengguna & 4.837 & 0.000 \\
Transaksi online -) Kepercayaan & 6.451 & 0.000 \\
Kepercayaan -) Kepuasan Pengguna & 2.032 & 0.043 \\
\hline
\end{tabular}

Sumber : Data Diolah, 2020

Hasil pengujian hipotesis 1 yakni pengaruh transaksi online terhadap kepuasan pengguna menunjukkan nilai $p$-value 0,000 sehingga nilai $p$ value lebih kecil dari level of significance 0,05. Maka bukti empiris menerima adanya pengaruh transaksi online terhadap kepuasan pengguna. Dengan demikian dapat disimpulkan bahwa transaksi online berpengaruh terhadap kepuasan pengguna dan $\mathrm{H} 1$ diterima.

Hasil pengujian koefisien pengaruh tidak langsung dengan mediator kepercayaan terhadap kepuasan pengguna, diperoleh $p$-value 0,000. Di mana $p$-value lebih kecil dari level of significance 0,05 . Hal ini menunjukkan bahwa kepercayaan mampu memediasi pengaruh transaksi online terhadap kepuasan pelanggan dan $\mathrm{H} 2$ diterima.

Transaksi online akan membentuk kepuasan pengguna dengan baik. Penelitian ini menunjukkan bahwa terdapat pengaruh transaksi online terhadap kepuasan pengguna Tokopedia di kota Cirebon. Hal ini memberikan makna bahwa semakin mudahnya melakukan transaksi online maka kepuasan pengguna atau indikator dalam variabel ini memiliki peran yang kuat baik dan merupakan faktor yang penting variabel penting dalam membentuk kepuasan pengguna yang maksimal. Dengan demikian dapat disimpulkan bahwa transaksi online yang dilakukan oleh penduduk di kota Cirebon akan membentuk kepuasan pengguna.
Dengan hasil temuan ini secara empiris pengelola marketplace harus lebih memperhatikan kemudahan dan kelancaran dalam melakukan transaksi online. Hal tersebut dapat membentuk kepuasan pelangguna yang maksimal. Secara empiris penelitian ini sejalan dengan penelitian penelitian terdahulu yang dilakukan oleh (Siregar Aisyah, 2020)(Mahaputra et al., 2020) yang memaparkan bahwa terdapat adanya hubungan antara transaksi online shopping dan kepuasan konsumen yang berpengaruh signifikan.

Dikarenakan dapat memberikan suatu dorongan kepada setiap konsumen untuk menjalin suatu ikatan yang kuat dengan perusahaan untuk memahami dengan seksama akan semua harapan konsumen dan kebutuhannya. Hasil analisa data untuk pengujian hubungan tidak langsung menunjukkan bahwa kepercayaan sebagai mediasi memiliki pengaruh secara positif dan signifikan antara transaksi online terhadap kepuasan pengguna. Penelitian ini juga mendukung penelitian yang dibuktikan oleh (Dhiranty et al., 2017) menyatakan bahwa hasil penelitiannya terjadi adanya hubungan yang signifikan antara transaksi online shopping dan kepuasan konsumen dimediasi kepercayaan konsumen..

Pada hasil mediasi menggambarkan bahwa kepercayaan mampu menghubungkan variabel transaksi online dan kepuasan pengguna. Keper- 
Fatimah, S.E., Purdianto, A., Septiani, D. \& Azzahra, N. (2021). Kepercayaan Sebagai Mediasi Kepuasan Pengguna Online ...

cayaan pada pengaruh transaksi online terhadap kepuasan pengguna berperan sebagai mediasi parsial yang artinya transaksi online dapat membentuk kepuasan pengguna secara langsung dan melalui mediasi kepercayaan. Secara empiris hasil analisis membuktikan bahwa kepercayaan mampu menjadi variabel intervening yang berperan sebagai mediasi pada hubungan transaksi online terhadap kepuasan pengguna secara parsial. Jadi transaksi online terhadap kepuasan pengguna dengan ada atau tidak adanya keper-cayaan sudah mampu meningkatkan kepuasan pengguna shopping online.

Kondisi di lapangan transaksi online yang digunakan oleh pengguna online shopping sudah cukup baik dan proses pembentukan kepuasan tidak mengalami kendala, yang berarti masyarakat kota Cirebon memiliki kepercayaan yang kuat dalam membentuk kepuasan pengguna online shopping.

\section{SIMPULAN}

Penelitian ini menemukan bahwa melakukan transaksi online dengan kemudahan dan kelancaran mempengaruhi kepuasan pengguna online shopping. Selanjutnya kepercayaan mempengaruhi kepuasan pengguna secara signifikan dalam melakukan transaksi online. Penelitian ini juga membuktikan bahwa kepercayaan juga merupakan mediator yang signifikan antara transaksi online dengan kepuasan pengguna aplikasi Tokopedia di kota Cirebon.

Para marketplace dapat memanfaatkan peluang ini dengan memberikan kenyamanan pengguna pada saat melakukan transaksi online dan meningkatkan kepercayaan pengguna dengan memberikan informasi yang akurat dalam memasarkan produknya.

\section{DAFTAR PUSTAKA}

Andhini, A., \& Khuzaini. (2017). Pengaruh Transaksi Online Shopping, dan Kepercayaan Konsumen Terhadap Kepuasan Konsumen pada Ecommerce. Jurnal Ilmu Dan Riset Manajemen, 6(7), 1-23. Retrieved from http://jurnalmahasiswa.stiesia.ac.id/index.php/ji $\mathrm{rm} /$ article/view/1753/1763

Chan, B., Purwanto, E., \& Hendratono, T. (2020). Social media marketing, perceived service quality consumer trust and online purchase intentions. Social Media Marketing, Perceived Service Quality, Consumer Trust and Online Purchase Intentions, 62(10), 6265-6272.

Dhiranty, A., Suharjo, B., \& Suprayitno, G. (2017). An Analysis On Customer Satisfaction, Trust And Loyality Toward Online Shop (A Case Study Of Tokopedia.COM). Indonesian Journal of Business and Entrepreneurship. https://doi.org/10.17358/ijbe.3.2.102

Indratno, D. L., \& Ramaini, S. (2018). Pengaruh Kepuasan Transaksi Online Dan Kepercayaan Terhadap Sikap Konsumen Pada E-Commerce (Studi Kasus Pembelian Produk Lazada.CO.ID Pada Mahasiswa Di Kota Yogyakarta). Jurnal Bisnis Teori Dan Implementasi, 9(2), 146-157.

Insana, D. R. M., \& Johan, R. S. (2020). Peningkatan Kepuasan Konsumen Melalui Penggunaan ECommerce. Sosio E-Kons, 12(02), 125. https://doi.org/10.30998/sosioekons.v12i02.64 51

Kotler, P., \& Kartajaya, Hermawan Setiawan, I. (2019). Marketing 4.0: Bergerak dari Tradisional ke Digital | Philip Kotler,. Book. Retrieved from https://b-ok.asia/book/5594406/b5bd48

Kotler, P., \& Keller, K. L. (2016). Marketing Mangement. In Pearson Edition Limited.

Latifah, N., Widayani, A., \& Normawati, R. A. (2020). Pengaruh Perceived Usefulness Dan Trust Terhadap Kepuasan Konsumen Pada ECommerce Shopee. BISMA: Jurnal Bisnis Dan Manajemen, $14(1), \quad 82$ https://doi.org/10.19184/bisma.v14i1.13550

Mahaputra, M. R., Djumarno, Afiah, N., Engriani, Y., Novaris, A., Penelitian, M. M., ... Hidayati, N. (2020). Pengaruh Store Atmosphere, Inovasi Produk Dan Customer Experience Terhadap Kepuasan Pelanggan Cafe Warunk Upnormal Di Banjarmasin Kalimantan Selatan. Jurnal Bissmart, 1(1), 1-23.

Mahendra, K. P., \& Indriyani, R. (2018). Pengaruh Kepercayaan Pelanggan Terhadap Kepuasan Pelanggan CV Mitra Perkasa Utomo. Agora, 7(1).

Mahsyar, S., Suharno, S., \& Abidin, Z. (2020). the Effect of Customer Trust and Company Image on 
Customer Satisfaction and Customer Loyalty in Indonesia Classification Bureau in Samarinda. International Journal of Economics, Business and Accounting Research (IJEBAR), 4(03), 27-39. https://doi.org/10.29040/ijebar.v4i03.1282

Merdekawati Agustiena, Elvi Sunita Evi, M. S. (2021). Pengaruh Kualitas Aplikasi Mobile, Kepercayaan, Harga, Dan Promosi Terhadap Kepuasan Konsumen Pada Era Pandemi Covid 19. 6, 156173. Retrieved from https://emea.mitsubishielectric.com/ar/product s-solutions/factory-automation/index.html

Nirawati, L., Ayu, B., Safitri, D., \& Ahmad, R. F. (2020). Pengaruh Kemudahan Transaksi dan Kepercayaan Produk Loyalitas Pelanggan Gojek (Studi Pada Mahasiswa Aktif Administrasi Bisnis UPN "Veteran" Jawa Timur). Jurnal Syntax Idea, 2(9), 594-604.

Nurhadi, N., \& Azis, A. (2018). Pengaruh Kualitas Pelayanan Terhadap Kepercayaan Dan Kesetiaan Konsumen. Jurnal Economia, 14(1), 89. https://doi.org/10.21831/economia.v14i1.1313 0

Purthi, C. D., \& Gupta, P. (2017). The Impact Of Online Shopping On Customer Satisfaction In Mr . Chander Deep Purthi , (Research Scholar ). 5(5), 1-11.

Rahmandika, Y. F., Puji, L., \& Purwanto, H. (2020). Analisis Pengaruh Harga Dan Kualitas Pelayanan Terhadap Kepuasan Konsumen. EKOBIS: Jurnal Ilmu Manajemen Dan Akuntansi, 8(1), 65-74. https://doi.org/10.36596/ekobis.v8i1.319

Siregar Aisyah, R. (2020). (2020). Pengaruh Transaksi Online Shopping, Kepercayaan Dan Risiko Terhadap Kepuasan Konsumen Pada E-Commerce. $1(2)$.

Sudaryana, Y. (2020). Pengaruh Kualitas Pelayanan,
Kepercayaan Dan Harga Terhadap Kepuasan Konsumen Pada Kantor Pos Indonesia (Persero) Kota Tangerang. Journal of Management Review, 4(1), 447-455.

Sugara, A., \& Dewantara, R. (2017). Analisis Kepercayaan Dan Kepuasan Terhadap Penggunaan Sistem. Administrasi Bisnis, 52(1), 815.

Sugiono. (2014). Metode Penelitian Kuantitatif, Kualitatif, dan Tindakan.

Sumarno, \& Alvin. (2021). Transaksi Online Shop dapat Meningkatkan Kepercayaan dan Kepuasan Konsumen dalam Perspektif Islam. Ecobankers ..., 2, 16-21. Retrieved from http://journal.bungabangsacirebon.ac.id/index.p hp/EcoBankers/article/view/309

Susilo, H., Haryono, A. T., \& Mukery, M. (2018). Analisis Pengaruh Harga, Kualitas Pelayanan, Promosi, dan Kepercayaan terhadap Kepuasan Konsumen dengan Keputusan Berkunjung sebagai Variabel Intervening di Hotel Amanda Hills Bandungan. Jurnal Manajemen Unpad, 4(4), 1-20. Retrieved from

http://jurnal.unpand.ac.id/index.php/MS/article /view/989

Widjaja, Restiani, Y., \& Araufi, A. (2020). Persepsi Nilai dan Kepercayaan Pelanggan Terhadap Kepuasan Pelanggan CV Putra Wangi Sumedang Tour and Travel. Jurnal Sain Manajemen, 2(1).

Wulur, L. M., Militina, T., \& Achmad, G. N. (2020). Effect of Service Quality and Brand Trust on Customer Satisfaction and Customer Loyalty Pertamina Hospital Balikpapan. International Journal of Economics, Business and Accounting Research (IJEBAR), 4(01), 72-83. https://doi.org/10.29040/ijebar.v4i01.908 